\title{
Sosialisasi Menjaga Kesehatan Fisik dan Psikologis selama Masa Pandemi COVID-19 secara Daring di Kota Bandung
}

\author{
Ahmad Mumtaz Tauba*1 \\ ${ }^{1}$ Departemen Keperawatan Jiwa, Fakultas Keperawatan, Institut Kesehatan Rajawali, Indonesia \\ *e-mail: tobatajama@gmail.com ${ }^{1}$
}

\begin{abstract}
Abstrak
Kurangnya tingkat pengetahuan masyarakat tentang cara menjaga kesehatan fisik dan psikologis selama masa pandemi COVID-19 dapat berdampak buruk dalam upaya menghindari masalah kesehatan yang disebabkan oleh COVID-19, hal ini menjadi indikasi perlunya upaya untuk meningkatkan pengetahuan terkait COVID-19. Salah satu upaya meningkatkan pengetahuan masyarakat adalah dengan memberikan informasi melalui pendidikan kesehatan dalam bentuk sosialisasi secara daring. Untuk meningkatkan pengetahuan masyarakat tentang upaya menjaga kesehatan fisik dan psikologis selama masa pandemi COVID-19 melalui sosialisasi secara daring. Metode yang digunakan adalah pre dan post-test tanpa kelompok kontrol. Teknik pengambilan sampel menggunakan sampling kuota sebanyak 50 sampel. Instrumen penelitian menggunakan instrumen tingkat pengetahuan tentang COVID-19. Didapatkan tingkat pengetahuan responden sebelum diberikan pendidikan kesehatan adalah pengetahuan kurang sebanyak 28 (56\%) responden, cukup sebanyak 18 (26\%) responden dan baik sebanyak 4 (8\%) responden. Setelah diberikan pendidikan kesehatan tingkat pengetahuan responden menjadi pengetahuan kurang sebanyak 2 (4\%) responden, cukup sebanyak 9 (18\%) responden dan baik sebanyak 39 (78\%) responden. Berdasarkan output test statistics di ketahui nilai $p$ value bernilai $<0,001$. Dapat di simpulkan terdapat pengaruh pendidikan kesehatan melalui sosialisasi secara daring terhadap tingkat pengetahuan masyarakat dalam menjaga kesehatan fisik dan psikologis selama masa pandemi COVID-19.
\end{abstract}

Kata kunci: COVID-19, Kesehatan Fisik, Kesehatan Mental

\section{Abstract}

The lack of public knowledge about how to maintain physical and psychological health during the COVID-19 pandemic can have a negative impact on efforts to avoid health problems caused by COVID-19, this is an indication of the need for efforts to increase knowledge related to COVID-19. One of the efforts to increase public knowledge is to provide information through health education in the form of online socialization. To increase public knowledge about efforts to maintain physical and psychological health during the COVID-19 pandemic through online socialization. The method used is pre and post test without a control group. The sampling technique used a quota sampling of 50 samples. The research instrument uses a knowledge level instrument about COVID-19. It was found that the level of knowledge of respondents before being given health education was less knowledge as many as $28(56 \%)$ respondents, 18 (26\%) respondents were sufficient and 4 (8\%) respondents were good. After being given health education the level of knowledge of the respondents became less knowledgeable as many as $2(4 \%)$ respondents, 9 (18\%) respondents were sufficient and 39 (78\%) respondents were good. Based on the output test statistics, it is known that the $p$ value is $<0.001$. It can be concluded that there is an effect of health education through online socialization on the level of public knowledge in maintaining physical and psychological health during the COVID-19 pandemic.

Keywords: COVID-19, Mental Health, Physical Health

\section{PENDAHULUAN}

World Health Organitation (WHO) secara resmi menyatakan virus corona COVID-19 sebagai pandemic. Menurut WHO, pandemic adalah skala penyebaran penyakit yang terjadi secara global di seluruh dunia. Namun, ini tidak memiliki sangkut paut dengan perubahan pada karakteristik penyakitnya. Suatu penyakit yang diresmikan sebagai pandemic artinya WHO memberi alarm pada pemerintah semua Negara dunia untuk meningkatkan kesiapsiagaan untuk mencegah maupun menangani wabah. Hal ini dikarenakan saat sebuah pandemic dinyatakan, artinya ada kemungkinan penyebaran komunitas terjadi. 
Istilah pandemic ini menyoroti pentingnya Negara-negara di seluruh dunia untuk bekerja secara kooperatif dan terbuka satu sama lain dan bersatu sebagai front persatuan dalam upaya untuk mengendalikan situasi ini. Semua Negara diminta untuk mendeteksi, mengetes, merawat, mengisolasi, melacak dan mengawasi pergerakan masyarakatnya. Pemahaman terhadap karakteristik pathogen baru menjadi kunci pengendalian di masa mendatang.

Berdasarkan data dari WHO, organ pernapasan menjadi sasaran utama infeksi virus corona. Sebanyak $87,9 \%$ pasien mengalami gejala demam, batuk kering $(67,7 \%)$ dan kelelahan $(28,1 \%)$. Penyakit paling umum setelah terinfeksi adalah pneumonia. Sekitar $14 \%$ mengalami gejala sedang (severe cases) seperti sulit bernafas, kekurangan oksigen dalam darah serta penurunan fungsi paru-paru. Sementara 5\% lainnya dalam kondisi kritis. Penelitian tentang pola penyebaran COVID-19 masih terus berlanjut, termasuk tingkat keparahan penyakit setelah terinfeksi.

Angka penyebaran covid yang semakin meningkat dikarenakan ketidakpatuhan masyarakat dalam menaati peraturan yang telah dibuat oleh pemerintah untuk memutus rantai penyebaran virus. Hal tersebut terjadi salah satunya disebabkan oleh masyarakat yang belum paham bahkan acuh terhadap dampak dari virus corona dan disisi lain tentunya ada faktor ekonomi yang menjadikan masyarakat tetap beraktifitas diluar rumah sehingga angka penyebaran covid dapat terjadi sangat cepat setiap harinya.

Banyak dampak yang diakibatkan oleh adanya pandemic ini, salah satunya yang terjadi pada Aspek pendidikan. Dengan adanya COVID-19 mengharuskan mahasiswa dan dosen melakukan bimbingan belajar dari rumah atau daring. Pun dilakukan dalam berbagai tingkat mulai dari TK, SD, SMO, SMA dan Kuliah. System yang digunakan juga berbeda, TK sampai SMA belajar dirumah dengan bimbingan orang tua melalui media televisi melibatkan satu stasiun TV. Untuk jenjang kuliah proses belajar dan ujian dilakukan online, kebijakan tiap kampus berbeda bahkan cara belajar mengajar yang diterapkan tiap dosen pun berbeda. Banyak aplikasi pendukung yang digunakan dalam belajar online. Diskusi dan pengerjaan tugas dapat melalui google classroom, Schoology, Zoom, dan link yang sudah disediakan oleh kampus.

Berdasarkan hasil penelitian Heidemans et all. (2021) menjelaskan bahwa edukasi secara daring melalui media sosial dapat mengurangi resiko penularan COVID-19 sekaligus sebagai upaya mendukung keberhasilan pemerintah dalam mengatasi COVID-19. Sementara itu menurut hasil survey yang dilakukan oleh Katharina, Pebrianti \& Melinda (2020) terhadap 114 KK di Desa Arang Limbung, ditemukan bahwa 97\% KK memiliki pengetahuan kurang baik tentang protokol kesehatan selama masa pandemi COVID-19. Pembelajaran tematik berbasis kearifan lokal dapat menjadi penghubung dalam memahamkan siswa di era pandemi COVID-19 (Daryanti et al., 2021).

Hasil penelitian Limoy \& Margareta (2020) dari 41 responden penelitian terdapat 35 responden (85\%) yang tidak memahami pentingnya menjaga protokol kesehatan sebagai upaya menghindari infeksi COVID-19. Diperkuat oleh hasil temuan Yuliana \& Diana (2020) yang menjelaskan bahwa dari 100 responden yang diteliti hampir semuanya yaitu 71 responden tidak mengetahui dengan jelas tentang COVID-19 dan juga tidak memahami cara mencuci tangan yang benar.

Pendidikan kesehatan merupakan program kesehatan yang berbasis komunitas maupun sekolah yang memiliki fokus pada promosi kesehatan dan pencegahan penyakit (Potter \& Perry, 2009). Strategi promosi kesehatan harus berfokus pada area-area penting yang merupakan isu besar yang dialami oleh individu, kelompok atau masyarakat yang dijadikan sebagai sasaran. Beberapa topik dapat di pilih untuk program pendidikan kesehatan terkait isu-isu tersebut sesuai dengan audiens yang menjadi target. Ide program pendidikan kesehatan yang berkaitan dengan seksualitas salah satunya adalah hygiene personal (Anderson \& McFarlane, 2006).

Pendidikan kesehatan merupakan ide utama dalam pelayanan primer/ pencegahan yang dapat dilakukan pada lingkungan klien seperti sekolah, kamar periksa, klinik dan pusat keperawatan. Fokus pendidikan kesehatan adalah menjaga manusia selalu sehat dengan topik edukasi kesehatan dalam pemeliharaan dan pencegahan penyakit yang salah satunya berkaitan dengan hygiene (Potter \& Perry, 2009). Pendidikan kesehatan/ promosi kesehatan dapat digunakan untuk keperawatan. Perawat membutuhkan pengetahuan tentang promosi kesehatan dikarenakan dalam semua bidang keperawatan baik keperawatan dasar, keperawatan 
maternitas, keperawatan anak, keperawatan jiwa, keperawatan medikal bedah maupun keperawatan komunitas akan membutuhkan layanan promosi kesehatan (Susilowati, 2016).

Pendidikan kesehatan dalam bentuk sosialisasi menjaga kesehatan fisik dan psikologis selama masa pandemi COVID-19 ini dilaksanakan secara daring atau online. Daring memiliki makna saling bertukar informasi dengan media yang terhubung melalui jaringan internet, pendidikan kesehatan secara daring merupakan suatu proses interaksi pembelajaran dengan menggunakan komputer/smartphone dan yang memiliki akses internet (Kahfi, 2020). Pelaksanaan pendidikan kesehatan secara daring tetap dapat dilakukan secara maksimal dan sangat relevan dengan selama masa pandemi COVID-19 dimana peserta dapat mengikuti pendidikan kesehatan dengan tetap menjaga jarak demi mencegah penyebaran COVID-19 serta mematuhi aturan tidak berkumpul di satu tempat.

Pendidikan kesehatan bertema COVID-19 dalam bentuk sosialisasi secara daring ini diharapkan dapat meningkatkan kesadaran, kepedulian dan juga pengetahuan masyarakat tentang cara menjaga kesehatan fisik dan psikologis selama masa pandemi COVID-19 sehingga masyarakat dapat ikut berpartisipasi langsung guna menekan angka penularan COVID-19.

\section{METODE}

Kegiatan pengabdian kepada masyarakat dilaksanakan secara daring melalui paparan webinar dengan aplikasi zoom dan live stream youtube dengan tema sosialisasi berupa "Menjaga kesehatan fisik dan psikologis selama masa pandemi COVID-19". Alat ukur menggunakan kuesioner pengetahuan tentang COVID-19 dari Louay Labban et al (2020), kuesioner terdiri dari 20 pertanyaan dengan pilihan jawaban menggunakan skala Guttman dengan skor 1 apabila jawaban ya, dan skor 0 apabila jawaban tidak. Hasil pengukuran pengetahuan tentang COVID-19 dibagi menjadi 3 (tiga) kategori sebagai berikut: a). Kurang jika jawaban benar $<50 \%$. b). Cukup jika jawaban benar 56-75\%. c). Baik jika jawaban benar $>76 \%$.

Metode yang digunakan berupa pre eksperimen dengan one group pre and post-test design yaitu pendekatan dengan pre dan post-test tanpa kelompok kontrol. Analisis data menggunakan analitik bivariat komparatif kelompok kategorik berpasangan yang bertujuan untuk mengetahui pengaruh pendidikan kesehatan terhadap tingkat pengetahuan tentang COVID-19.

\section{HASIL DAN PEMBAHASAN}

Tabel 1 menunjukan bahwa sebelum diberikan intervensi pendidikan kesehatan sebagian besar responden memiliki kategori tingkat pengetahuan kurang yaitu sebanyak 32 (54\%) responden, sebanyak 19 (36\%) responden memiliki pengetahuan cukup dan sebanyak 8 (14\%) responden memiliki pengetahuan baik.

Tabel 1. Distribusi Frekuensi Tingkat Pengetahuan tentang COVID-19 Sebelum Diberikan Intervensi Pendidikan Kesehatan

\begin{tabular}{ccc}
\hline $\begin{array}{c}\text { Tingkat Pengetahuan } \\
\text { (Pretest) }\end{array}$ & $\begin{array}{c}\text { Frekuensi } \\
\text { (n) }\end{array}$ & $\begin{array}{c}\text { Presentase } \\
\text { (\%) }\end{array}$ \\
\hline Kurang & 32 & 54 \\
Cukup & 19 & 32 \\
Baik & 8 & 14 \\
Total & 59 & 100 \\
\hline
\end{tabular}

Tabel 2 menunjukan bahwa sesudah diberikan intervensi pendidikan kesehatan sebagian besar responden memiliki kategori tingkat pengetahuan baik yaitu sebanyak 43 (72\%) responden, sebanyak 12 (20\%) responden memiliki pengetahuan cukup dan sebanyak 4 (8\%) responden memiliki pengetahuan kurang. 
Tabel 2. Distribusi frekuensi tingkat pengetahuan tentang COVID-19 sesudah diberikan intervensi pendidikan kesehatan.

\begin{tabular}{ccc}
\hline $\begin{array}{c}\text { Tingkat Pengetahuan } \\
\text { (Post-test) }\end{array}$ & $\begin{array}{c}\text { Frekuensi } \\
\text { (n) }\end{array}$ & $\begin{array}{c}\text { Presentase } \\
\text { (\%) }\end{array}$ \\
\hline Kurang & 4 & 8 \\
Cukup & 12 & 20 \\
Baik & 43 & 72 \\
Total & 59 & 100 \\
\hline
\end{tabular}

Pada pengabdian kepada masyarakat ini didapatkan tingkat pengetahuan responden sesudah diberikan intervensi sosialisasi dalam menjaga kesehatan fisik dan psikologis selama masa pandemi COVID-19 (post-test) masuk dalam kategori pengetahuan kurang sebanyak 2 (4\%) responden, kategori pengetahuan cukup sebanyak 9 (18\%) responden dan kategori pengetahuan baik sebanyak $39(78 \%)$ responden. Jika di uraikan dari setiap soal yang terdapat dalam kuesioner jumlah persentase setiap soal yang dijawab "benar" atau bernilai "1" oleh responden meningkat dari sebelumnya 18\% - 96\% pada hasil pretest menjadi $60 \%$ - 98\% pada hasil post-test. Pertanyaan-pertanyaan pada hasil pretest dengan persentase jawaban "benar/bernilai 1" paling sedikit secara keseluruhan meningkat persentase jawaban benarnya pada hasil post-test.

Berdasarkan data hasil penelitian diatas menunjukan bahwa pemberian intervensi pendidikan kesehatan dapat meningkatkan pengetahuan responden mengenai COVID-19. Hal ini dikarenakan dalam proses pemberian intevensi pendidikan kesehatan, responden menerima informasi yang kemudian informasi tersebut mempengaruhi tingkat pengetahuannya. Hal ini sesuai dengan teori yang menyatakan bahwa informasi mempengaruhi pengetahuan seseorang, jika dia sering mendapatkan informasi tentang sesuatu maka akan menambah pengetahuan dan wawasannya (Budiman \& Riyanto, 2013).

Menurut Gustina \& Djannah (2015) terdapat hubungan yang bermakna secara statistik antara sumber informasi dengan pengetahuan pada siswa dengan nilai $\mathrm{p}<0,05$. Berdasarkan hasil penelitian lain diketahui bahwa ada hubungan antara sumber informasi dengan pengetahuan. Dengan hasil uji statistik diketahui bahwa nilai $r$ sebesar 0,753 dengan nilai signifikansi 0,000 $(\mathrm{p}<0,05)$, yang menunjukkan ada hubungan antara sumber informasi dengan pengetahuan yang memiliki hubungan sangat kuat dan bersifat positif, yang berarti bahwa semakin banyak sumber informasi yang didapat oleh seorang semakin baik pula pengetahuannya, begitu juga sebaliknya (Rahmawati et al, 2011).

Berdasarkan hasil penelitian sebelumnya menyatakan bahwa pemberitahuan informasi melalui pendidikan dan penyuluhan akan meningkatkan pengetahuan, selanjutnya pengetahuan akan menimbulkan kesadaran yang pada akhirnya kesadaran tersebut membuat remaja berperilaku sesuai dengan pengetahuan yang dimiliki, tentunya hal ini memerlukan waktu yang cukup lama (Maulana, 2019).

\section{KESIMPULAN}

Sebagian besar responden pada awalnya memiliki kategori tingkat pengetahuan kurang yaitu sebanyak $28(56 \%)$ responden, sebanyak 18 (36\%) responden memiliki pengetahuan cukup dan sebanyak $4(8 \%)$ responden memiliki pengetahuan baik. Sesudah diberikan intervensi pendidikan kesehatan dalam bentuk sosialisasi menjaga kesehatan fisik dan psikologis selama masa pandemi COVID-19 sebagian besar responden memiliki kategori tingkat pengetahuan baik yaitu sebanyak $39(78 \%)$ responden, sebanyak $9(18 \%)$ responden memiliki pengetahuan cukup dan sebanyak 2(4\%) responden memiliki pengetahuan kurang.

\section{DAFTAR PUSTAKA}

Anderson \& McFarlane. (2006). Buku Ajar Keperawatan Komunitas: Teori dan Praktek. Jakarta: EGC. 
Arrum, A. H., \& Fuada, S. (2021). Penguatan Pembelajaran Daring di SDN Jakasampurna V Kota Bekasi, Jawa Barat Menggunakan Media Pembelajaran Interaktif Berbasis Augmented Reality (AR). ABDIMAS: Jurnal Pengabdian Masyarakat, 4(1), 502-510.

Budiman \& Riyanto. (2013). Kapita Selekta Kuisioner Pengetahuan Dan Sikap Dalam Penelitian Kesehatan. Jakarta: Salemba Medika.

Daryanti, T., Chusna, R., Faridhatul, K., Suryani, Y. E., Darmo, M. P., Nugroho, A. J. S., \& Darupratomo, D. (2021). PROGRAM KKN-TEMATIK PEMBELAJARAN BERBASIS KEARIFAN LOKAL DI SEKOLAH DASAR KABUPATEN KLATEN PADA ERA PANDEMI COVID-19. Prosiding, 10(1).

Gustina, E., \& Djannah, S. N. (2015). Sumber informasi dan pengetahuan tentang menstrual hygiene pada remaja putri. KEMAS: Jurnal Kesehatan Masyarakat, 10(2), 147-152.

Heidemans, N. A., Lombogia, R., Siwu, I. C., \& Kenang, R. C. (2021). Kegiatan Kuliah Kerja Nyata di Masa Pandemi COVID-19. DEDICATIO: Jurnal Pengabdian Kepada Masyarakat, 2(1), 31-40.

Iit, K., Rofiyani, L., Lina, A., \& Darhayati, N. (2020). PEMAHAMAN MASYARAKAT TERHADAP COVID-19 DALAM MASA NORMAL BARU DESA ARANG LIMBUNG RT/RW 004/005 KECAMATAN SUNGAI RAYA KABUPATEN KUBU RAYA TAHUN 2020. jurnal. pkm-komunitas. akpb. ac. id, 4(1), 13-16.

Kahfi, A. (2020). Tantangan Dan Harapan Pembelajaran Jarak Jauh Di Masa Pandemi Covid 19. Dirasah: Jurnal Pemikiran dan Pendidikan Dasar Islam, 3(02), 137-154.

Katharina, T., Pebrianti, D., \& Melinda, C. (2020). PENCEGAHAN PENYEBARAN COVID-19 DI DESA ARANG LIMBUNG KECAMATAN SUNGAI RAYA KABUATEN KUBU RAYA TAHUN 2020. jurnal. pkm-komunitas. akpb. ac. id, 4(1), 20-24.

Labban, L., Thallaj, N., \& Labban, A. (2020). Assessing the level of awareness and knowledge of COVID 19 pandemic among syrians. Arch Med, 12(2), 8.

Limoy, M., \& Margareta Ita, R. (2020). PEMAHAMAN MASYARAKAT TERHADAP COVID-19 DALAM MASA NORMAL BARU DESA ARANG LIMBUNG RT/RW 05/11 BERADA DI KECAMATAN SUNGAI RAYA KABUPATEN KUBU RAYA. jurnal. pkm-komunitas. akpb. ac. id, 4(1), 17-19.

Maulana, I., Suryani, S., Sriati, A., Sutini, T., Widianti, E., Rafiah, I., ... \& Senjaya, S. (2019). Penyuluhan Kesehatan Jiwa untuk Meningkatkan Pengetahuan Masyarakat tentang Masalah Kesehatan Jiwa di Lingkungan Sekitarnya. Media Karya Kesehatan, 2(2).

Potter \& Perry. (2009). Fundamental Keperawatan (Fitriani DN, et al, editor Bahasa Indonesia). 7th ed. Singapore: Elsevier.

Rahmawati, C. T. (2010). Hubungan antara sumber informasi dan pengetahuan tentang menstruasi dengan perilaku personal hygiene selama menstruasi pada siswi smp ni kebonarum Kabupaten klaten (Doctoral dissertation, Universitas Muhammadiyah Surakarta).

Susilowati. (2016). Promosi Kesehatan: Modul Bahan Ajar Cetak Keperawatan. Jakarta: Hak Cipta Kementrian Kesehatan Republik Indonesia.

Yuliana, A., \& Diana, M. (2020). EDUKASI DAN PENCEGAHAN PENULARAN VIRUS COVID-19 PADA MASYARAKAT DESA PARIT BARU DAN PARIT ADONG KABUPATEN KUBU RAYA TAHUN 2020. jurnal. pkm-komunitas. akpb. ac. id, 4(1), 8-12. 


\section{Halaman Ini Dikosongkan}

